\title{
Effect of habitat and sex on biological indicators and blood biochemistry of Andinoacara rivulatus in the province Los Ríos - Ecuador
}

Efecto del hábitat y el sexo sobre indicadores biológicos y la bioquímica sanguínea de Andinoacara rivulatus en la provincia Los Ríos - Ecuador

Efeito do habitat e do sexo nos indicadores biológicos e na bioquímica do sangue na Andinoacara rivulatus provincia Los Ríos - Equador

Yuniel Méndez-Martínez ${ }^{1 *}$ (잉 (D)

Mariuxi F. Cevallos-Chevez ${ }^{1}$ (a) (D)

Yenny G. Torres-Navarrete ${ }^{1}$ (영 (D)

Edilmar Cortés-Jacinto ${ }^{2}$ (a) (1)

Jorge L. Ramírez-de la Ribera ${ }^{3}$ 잉 (D)

Rev. Fac. Agron. (LUZ). 2022, 39(1): e223910

ISSN 2477-9407

DOI: https://doi.org/10.47280/RevFacAgron(LUZ).v39.n1.10

\section{Animal Production}

Associate editor: Dr. Rosa Razz
${ }^{1}$ Facultad de Ciencias Agropecuarias, Universidad Técnica Estatal de Quevedo (UTEQ), Quevedo, Los Ríos, Ecuador. ${ }^{2}$ Programa de Acuicultura, Centro de Investigaciones Biológicas del Noroeste (CIBNOR), La Paz, BCS, México. ${ }^{3}$ Centro de Estudio de Producción Animal, Universidad de Granma (UDG), Bayamo, Granma, Cuba.

Received: 07-09-2021

Accepted: 19-10-2021

Published: 03-01-2022

\section{Keywords: \\ Cholesterol \\ Condition factor \\ Freshwater fish \\ Gonadosomatic index \\ Glucose}

\begin{abstract}
The effect of the habitat and sex on biological indicators and blood biochemistry of Andinoacara rivulatus in the province of Los Ríos - Ecuador was evaluated. Were captured 60 specimens for each zone (180 total), the eight of the animals, length, thickness of the head, tail and the factor were evaluated. Blood glucose, cholesterol and triglyceride indicators were determined. A completely randomized design was used with factorial arrangement (three $\mathrm{x}$ two), three habitats and two sexes. A double classification analysis of variance was applied considering the habitat and sex as sources of variation. The results showed the highest morphometric values for males and varied with the habitat, except in the body indices, what were the females. The functional relationship between length and weight was established using quadratic regression equations, with greater significance for males with $\mathrm{r}^{2}$ greater than 0.70 . No interaction between zones and sex was shown for the blood indicators studied. The results showed interaction between the habitat locations and sex for the different morphometric indicators evaluated. The biochemical indicators of the blood were conditioned by the habitat.
\end{abstract}


2-6 | Rev. Fac. Agron. (LUZ). 2022, 39(1): e223910. January - March. ISSN 2477-9407.

\section{Resumen}

Se evaluó el efecto del habitat y el sexo sobre indicadores biológicos y bioquímica sanguínea de Andinoacara rivulatus en la provincia de Los Ríos, Ecuador. Se capturaron 60 ejemplares por cada zona (180 total). Se evaluaron los indicadores peso de los animales, longitud, grosor de la cabeza, cuerpo, la cola y factor de condición. Se determinaron los indicadores sanguíneos glucosa, colesterol y triglicéridos. Se empleó un diseño completamente aleatorizado con arreglo factorial tres $\mathrm{x}$ dos, tres habitat y dos sexos. Se le aplicó un análisis de varianza de clasificación doble considerando la zona de habitad y el sexo como fuentes de variación. Los resultados mostraron los mayores valores morfométricos para los machos y variaron con la localidad, excepto para los índices corporales, que fueron en las hembras. Se estableció la relación funcional entre el peso y la longitud mediante ecuaciones de regresión cuadráticas, con mayor significación para los machos con $\mathrm{r}^{2}$ superiores a 0.70 . No se mostró interacción entre las zonas y el sexo para los indicadores de la sangre estudiados. Los resultados mostraron interacción entre las localidades de hábitat y el sexo para los diferentes indicadores morfométricos evaluados. Los indicadores bioquímicos de la sangre estuvieron condicionados por la localidad.

Palabras clave: colesterol, factor de condición, glucosa, índice gonadosomático, peces de agua dulce.

\section{Resumo}

Foi avaliado o efeito do habitad e do sexo nos indicadores biológicos e na bioquímica do sangue de Andinoacara rivulatus na província de Los Ríos, Equador. 60 espécimes foram capturados para cada zona (180 total). Foram avaliados o peso dos animais, comprimento, espessura da cabeça, corpo, cauda e fator de condição. Foram determinados os indicadores sanguíneos de glicose, colesterol e triglicerídeos. O delineamento experimental foi inteiramente casualizado, com arranjo fatorial três $\mathrm{x}$ dois, três localidades e dois sexos. Uma dupla classificação de análise de variância foi aplicada considerando a área de habitat e sexo como fontes de variação. Os resultados mostraram os maiores valores morfométricos para os machos e variaram com a localidade, excetp nos indices corporais, quais eram as fêmeas. A relação funcional entre peso e comprimento foi estabelecida por meio de equações de regressão quadrática, com maior significância para o sexo masculino com r2 maior que 0.70. Nenhuma interação entre zonas e sexo foi mostrada para os indicadores sanguíneos estudados. Os resultados mostraram interação entre a localização do habitat e o sexo para os diferentes indicadores morfométricos avaliados. Os indicadores bioquímicos do sangue foram condicionados pela localidade.

Palavras-chave: colesterol, fator de condição, peixes de água doce, índice gonadossomático, glicose.

\section{Introduction}

Ecuador is considered an important reserve of native freshwater fish in the southeastern tropical Pacific, where 951 native species are recognized (Barriga, 2012; FAO, 2019). On the other hand, most Neotropical cichlids occupy habitats within slow-flowing lakes, rivers, and streams. The Andinoacara rivulatus (Cichlidae: Andinoacara) is a native fish of the Pacific basin, covering its distribution from
Panama to Peru, in addition to being of great ornamental importance, it is also a source of food and work for the populations that have these economic resources (Revelo and Laaz, 2012; Jiménez Prado et al., 2015).

The $A$. rivulatus is a species that lives in slow, shallow waters that are close to the shores, they feed near the rocks with vegetation, it also lives in the lower course of the rivers, with soft waters (turbid) or clear with a muddy background. Jiménez Prado et al. (2015), state that the height of the body is $2.6 \mathrm{~cm}$ of the total length, the length of the head is $2.8 \mathrm{~cm}$ of the total length. It has a tall body, laterally compressed and has four to five spots. Both males have a hump, and females have electric blue lines in the chin area and a black spot on the body (Jiménez Prado et al., 2015).

The phenotypic plasticity of fish, evaluated by morphological measurements, is higher than in the rest of vertebrates and this variation can be attributed in part to the influence of environmental parameters (González et al., 2016; Ahmadniaye Motlagh et al., 2020).

Physiological differences between gender are related to primary and secondary sexual characteristics and their adaptations, result of different strategies used for reproductive success, with marked differences in blood parameters between females and males due to a high metabolism in males. Although according to the report by Bastardo et al. (2004) that females have higher values in blood parameters. The variation of the results may be due to the different conditions in which the organisms were maintained in each study (Enayat Gholampour et al., 2020). The study of blood chemistry and morphometry are currently of great interest in determining the health status and metabolic balance in wild fish, since several intrinsic and extrinsic factors can influence blood parameters and morphometry in fish.

The determination of the morphometric values and the blood chemistry of the A. rivulatus in the province of these rivers will help to generate strategies for the conservation of the species and the lotic environments of the region. Due to the above, the objective of this work was to evaluate the effect of habitat and sex on biological indicators and blood biochemistry of A. rivulatus in the province Los Ríos, Ecuador.

\section{Materials and methods}

\section{Location}

This investigation was carried out in three areas of the Los Ríos province, Fumisa, Camarones area, geographically at coordinates $0^{\circ} 43^{\prime} 16^{\prime} \mathrm{S}$ and $79^{\circ} 27^{\prime} \mathrm{W}$; Pajarito precinct belonging to Mocache canton $1^{\circ} 8^{\prime} 03.92$ ' S, 79 $29^{\circ}$ '07.8' $\mathrm{W}$ and Quevedo, the route of the River $1^{\circ} 2^{\prime} 30^{\prime} \mathrm{S}$ and $79^{\circ} 28^{\prime} 30^{\prime} \mathrm{W}$ (figure 1). The climatic conditions are shown in table 1.

\section{Ethics statement}

The study was performed in strict accordance with the Standard Operation Procedures (SOPs) for Use of Experimental Animals of UTEQ (Quevedo, Los Ríos, Ecuador). The experimental protocol and procedures are approved by the Institutional Animal Care and Use Committee of UTEQ.

\section{Procedure}

This research was developed during the month of December-2019; One of the native freshwater species that are most commercialized in the cantons of Quevedo, Mocache and Fumisa of the Rivers Province, A. rivulatus was identified; Through artisanal fishing, 60 specimens were captured for each area (180 total), once captured, sexing was carried out taking into account the morphological characteristics (Nugra et al., 2018; Rodríguez Pulido et al., 2018). Males represented 47.78 percent of the total and $52.22 \%$. 


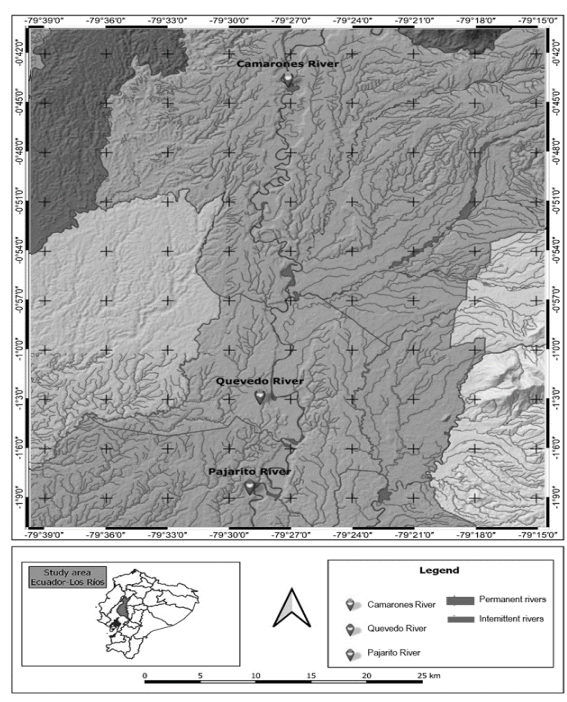

Figure 1. Map of sampling areas

Table 1. Annual climatic characteristics of three areas of province Los Ríos - Ecuador.

\begin{tabular}{cccc}
\hline Zone & $\begin{array}{c}\text { Temperature } \\
{ }^{\circ} \mathbf{C}\end{array}$ & $\begin{array}{c}\text { Precipitation } \\
\mathbf{~ m m}\end{array}$ & Weather \\
\hline Fumisa & $21-31$ & $2000-3500$ & Tropical \\
Mocache & $20-30$ & $1626-3500$ & Tropical semi-humid \\
Quevedo & $23-31$ & $1750-2500$ & Tropical humid \\
\hline
\end{tabular}

\section{Biology indicators}

The fish were weighed individually on a digital scale $\pm 0.01 \mathrm{~g}$ (PE 3600 Mettler-Toledo, Columbus, Ohio, USA), the length was determined with the help of a tape measure (Truper, $3 \mathrm{~m}$-Fh, Distrito Federal, MX) measuring from the tip of the mouth to the fin of the tail. To measure the thickness of the head, body and tail, a digital vernier caliper (GT-MA15 Gester, $\pm 0.001 \mathrm{~mm}$, Xiamen, CN) was used.

The Condition Factor was determined according to the following formula (Moreno et al., 2019):

-Condition Factor $=\left(\right.$ live weight $/$ total length $\left.{ }^{3}\right) \times 100$

The animals were dissected, which allowed the macroscopic classification of the gonad according to Holden and Raitt (1975). The following indices were subsequently calculated:

-Gonadosomatic index $=($ gonad weight $/$ body weight $) \times 100$

-Hepatosomatic index $=($ liver weight $/$ body weight $) \times 100$

Biochemistry in blood plasma

$1 \mathrm{~mL}$ of blood was extracted from the hemal arch by puncturing the caudal artery, for which three $\mathrm{mL}$ syringes were used (Bio-In, Guayaquil, EC); which were placed in capillary tubes (Isolab, Laborgeräte $\mathrm{GmbH}$, Eschau, $\mathrm{DE}$ ) with heparinized inner surfaces, then the samples were centrifuged (Gemmy, PLC-05, Taipei, TW) at $1200 \mathrm{rpm}$ for $10 \mathrm{~min}$ to obtain serum plasma and later determine the levels of glucose, cholesterol and triglycerides (Méndez Martínez et al., 2021). For which kit reagents were applied (Human liquicolor, Wiesbaden, DE); and they were incubated for $25 \mathrm{~min}$ at $37 \mathrm{oC}$ (Trinder, 1965). Readings were performed on a spectrophotometer (Sunostlk, SBA-733 Plus, Kunshan Road, CN) at ABS: $510 \mathrm{~nm}$ for glucose, $500 \mathrm{~nm}$ for cholesterol and triglycerides. The analyzes were carried out in triplicate.

Experimental design and statistical analysis

A completely randomized design was used with a three $\mathrm{x}$ two factorial arrangement, three localities Mocache (one), Fumisa (two) and Quevedo (three) and sexes females (one) and male (two).

An analysis of variance $(\mathrm{p} \leq 0.05)$ of classification double was applied considering the area of habitat and sex as sources of variation. The Kolmogorov-Smirnov $(\mathrm{p} \leq 0.05)$ and Bartlett $(\mathrm{p} \leq 0.05)$ tests were applied prior to the analysis of variance (ANOVA). The difference between the means was quantified using the Tukey $(\mathrm{p} \leq 0.05)$.

Regression equations were established to establish the functional relationship between length and weight. To select the expressions of best fit, the following elements were considered: high coefficient of determination $\left(\mathrm{r}^{2}\right)$, high significance, significant contribution of the terms and low coefficients of indeterminacy $\left(1-\mathrm{r}^{2}\right)$, standard errors of the terms, standard errors of estimation and mean square of the error. For data analysis, SPSS ${ }^{\circledR} 21.0$ software (Inc., Chicago, IL USA) was used.

\section{Results and discussion}

The results reflected that the interaction of the locality and sex showed the highest weight values of the animals for treatment four $290.93 \pm 28.3 \mathrm{~g}$, Fumisa locality $\mathrm{x}$ males, $(\mathrm{p}<0.05)$, with differences compared to the rest. Emphasizing that no differences were shown between treatments one, three and five (table 2).

Table 2. Biological indicators of the Andinoacara rivulatus according to habitat and sex interaction

\begin{tabular}{|c|c|c|c|c|c|c|c|c|c|c|}
\hline \multirow{2}{*}{$\begin{array}{l}\text { Interaction of } \\
\text { habitat and sex }\end{array}$} & \multicolumn{10}{|c|}{ Biological indicators } \\
\hline & $\begin{array}{l}\text { Weight, } \\
\text { g }\end{array}$ & $\begin{array}{c}\text { Length, } \\
\text { cm }\end{array}$ & Head & $\begin{array}{l}\text { thickness, } \\
\text { cm }\end{array}$ & Body & $\begin{array}{l}\text { thickness, } \\
\text { cm }\end{array}$ & $\begin{array}{l}\text { Tail thickness, } \\
\text { cm }\end{array}$ & $\begin{array}{c}\text { Condition fac- } \\
\text { tor }\end{array}$ & $\begin{array}{l}\text { Hepatoso-matic } \\
\text { index }\end{array}$ & $\begin{array}{c}\text { Gonado-somatic } \\
\text { index }\end{array}$ \\
\hline 1 & $168.19^{\mathrm{d}}$ & $21.25^{\mathrm{e}}$ & & $5.60^{\mathrm{d}}$ & & $9.26^{\mathrm{f}}$ & $6.26^{\mathrm{d}}$ & $1.88^{\mathrm{a}}$ & $1.40^{\mathrm{c}}$ & $14.51^{\mathrm{b}}$ \\
\hline 2 & $266.29^{b}$ & $26.90^{\mathrm{b}}$ & & $7.25^{\mathrm{a}}$ & & $12.34^{\mathrm{b}}$ & $8.53^{\mathrm{a}}$ & $1.37^{\mathrm{b}}$ & $0.91^{\mathrm{f}}$ & $8.52^{\mathrm{e}}$ \\
\hline 3 & $179.88^{\mathrm{d}}$ & $24.15^{\mathrm{c}}$ & & $6.51^{\mathrm{b}}$ & & $11.14^{\mathrm{d}}$ & $6.50^{\mathrm{c}}$ & $1.30^{\mathrm{c}}$ & $1.67^{\mathrm{a}}$ & $13.9^{\mathrm{c}}$ \\
\hline 4 & $290.93^{\mathrm{a}}$ & $28.11^{\mathrm{a}}$ & & $7.35^{\mathrm{a}}$ & & $13.24^{\mathrm{a}}$ & $7.51^{\mathrm{b}}$ & $1.39^{\mathrm{b}}$ & $1.38^{\mathrm{d}}$ & $8.49^{\mathrm{e}}$ \\
\hline 5 & $169.20^{\mathrm{d}}$ & $23.14^{\mathrm{d}}$ & & $6.18^{\mathrm{c}}$ & & $10.23^{\mathrm{e}}$ & $6.73^{\mathrm{c}}$ & $1.38^{\mathrm{b}}$ & $1.24^{\mathrm{e}}$ & $15.54^{\mathrm{a}}$ \\
\hline 6 & $225.40^{\mathrm{c}}$ & $26.24^{\mathrm{b}}$ & & $6.94^{\mathrm{b}}$ & & $11.96^{\mathrm{c}}$ & $7.33^{b}$ & $1.24^{\mathrm{c}}$ & $1.59^{\mathrm{b}}$ & $10.86^{\mathrm{d}}$ \\
\hline $\mathrm{SE}^{2} \pm$ & 7.51 & 0.39 & & 0.09 & & 0.21 & 0.13 & 0.05 & 0.05 & 0.62 \\
\hline$P$ & 0.001 & 0.01 & & 0.001 & & 0.002 & 0.002 & 0.001 & 0.001 & 0.003 \\
\hline
\end{tabular}

${ }^{1}$ Habitat $\mathrm{x}$ Sex interaction (1: Mocache $\mathrm{x}$ females, 2: Mochache $\mathrm{x}$ males, 3: Fumisa $\mathrm{x}$ females, 4: Fumisa $\mathrm{x}$ males, 5: Quevedo $\mathrm{x}$ females, and 6: Quevedo $\mathrm{x}$ males). 2 SE \pm , standard error of the Habitat $x$ Sex interaction. abcdeValues with unusual letters differ at $\mathrm{p}<0.05$, Tukey. 


\section{4-6 | Rev. Fac. Agron. (LUZ). 2022, 39(1): e223910. January - March. ISSN 2477-9407.}

Regarding length, something similar occurred and treatment four reflected the highest length, with differences $(\mathrm{p}<0.05)$ compared to the rest. Treatments two and six did not reflect a difference between them, and without with the rest. Body thickness showed the highest value for the fourth interaction, which differs from the rest, the lowest value was reflected in the first treatment (table 2). In the case of the thickness of the tail, interaction two presented the highest value and differed from the rest. Interactions four and six, as well as three and five did not show differences between them, and the lowest of the values was reflected for number one.

The condition factor showed the highest value for the first interaction, which differed from the rest. The number two, four and five did not present differences between them, something similar happened for three and six, which were in turn the lowest values.

The results reported according to the effect of the localitysex interaction (table 2), results that are corroborated by what was proposed by Turán et al. (2006), where he affirms that the introduction of a species of fish leads to a high adaptation to different geographies, which leads to phenotypic variations with respect to those that gave rise to it (Fagbuaro et al., 2015; Solomon et al., 2015). The previously explained is confirmed when evaluating the remaining indicators. For the thickness of the head, the highest values were reflected in treatments two and four with differences $(\mathrm{p}<0.05)$ compared to the rest. The lower thickness of the head was shown for the first interaction and differences between three and six were not reflected. In all these cases the highest values correspond to males and differences are established between localities. Studies carried out in Ecuador showed results similar to those of this research, in terms of morphometric characteristics such as: thickness of the head, body, tail and the condition factor (González, 2017). This is because the different parts of the body vary depending on environmental conditions and gender. Different authors highlight the variation of the morphometric characteristics of this species depending on the locality and sex (Solomon et al., 2015; González et al., 2016).

Hepatosomatic index (table 3) showed the highest value for treatment three (Fumisa $x$ females), with differences $(\mathrm{p}<0.05)$ with respect to the rest, and the lowest value was reflected by treatment two. For the gonadosomatic index the highest content was shown by treatment five, reflecting differences $(\mathrm{p}<0.05)$ with respect to the rest. The lowest appeared for treatment two, which reflects less precipitation than treatment three. In this sense, Kerguelen and Atencio (2015), reported that, in tropical aquatic systems, the hydrological patterns and the transport of nutrients generated by the rainy season are definitive for the selection of the optimal reproduction time.

This is related to the amount of rainfall depending on the location. Andrade and Braga (2005) affirm that the intensity of the rain is the most important factor in the synchronization of the reproduction of tropical fish, therefore coinciding the reproductive period with the rainy season may be an evolutionary strategy. The fish only have to find favorable habitat conditions for spawning and recruitment (Jiménez et al., 2016).

On the other hand, a study carried out in Ecuador in Eremophilus mutisii reflected that females presented higher hepatosomatic and gonadosomatic indices (Moreno et al. 2019). Similar to what happened in this work. This finding agrees with the records of Landines et al. (2017). In this way, it is to be assumed that after starting the gonadal maturation processes, the female must allocate a greater proportion of energy and nutrients towards the reproductive function to support a greater growth of the gonad (ovary) than the male.

The relationship between weight and length in the Mocache locality (figure 2a), reflected a coefficient above 0.70, with high significance of the terms of the equation for the case of males. However, for females, although there are differences in the model, the coefficient of determination is not high (0.48).

For the habitat of Fumisa and Quevedo (figure $2 b$ and $2 c$ ) the functional relationship between length and weight was shown by a quadratic regression equation with a high coefficient and significance of the terms of the equation. This did not happen for the females in Fumisa, where the terms of the equation did not show significance, and the coefficient of determination was low.

In the town of Quevedo, the relationship between length and weight was adjusted to a quadratic regression equation for both males and females, with high coefficients of determination in both cases (figure 2), and high significance of the terms of the equation.

Moreno et al. (2019), reported results that differ from those of this research, when evaluating the total length-weight relationship of Eremophilus mutisii in growing females and males, where it showed potential equations with $\mathrm{r}^{2}$ greater than 0.88 . These authors reported that the allometric coefficient of the length-weight relationship was numerically higher for maturing females than for males. The allometric coefficient was significant for both maturing females and males $(p<0.05)$. This is due to the fact that the increase in weight as a function of size is more accentuated in females than in males, especially during gonadal maturation. This difference can be explained to a large extent by the differences that exist in the weight of the gonads, where the gonadosomatic index was higher for maturing females when compared to that of males, an issue that did not occur in this experiment.

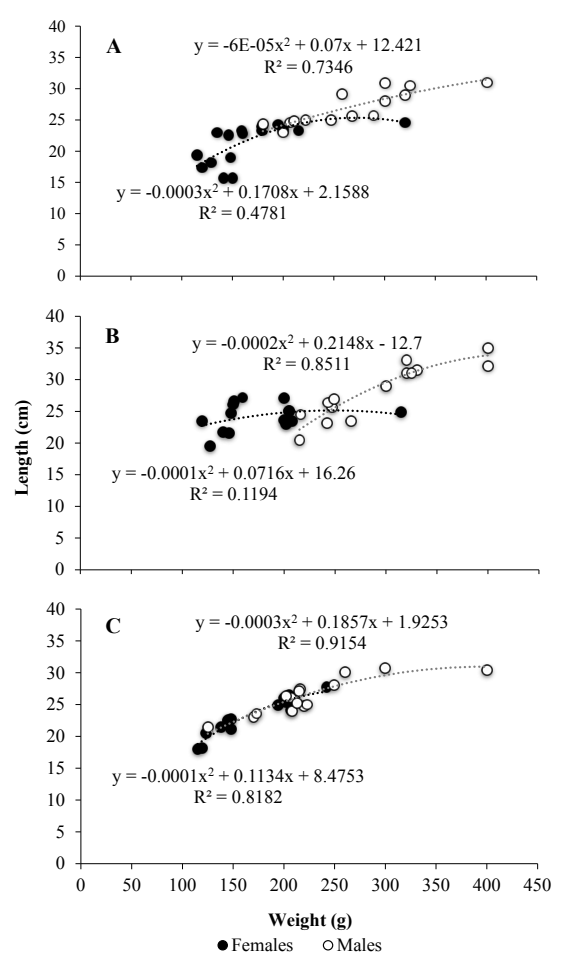

Figure 2. Length and weight relationship in males and females of Andinoacara rivulatus from three habitats a) Mocache, b) Fumisa and c) Quevedo. 
A study in Ecuador when evaluating the length-weight relationship of the main fish species (Andinoacara rivulatus, Hoplias microlepis, Rhamdia cinerascens, Brycon sp, Leporinus ecuadoriensis, Pseudocurimata sp) of commercial interest in the Abras of Mantequilla wetland, Ecuador (Ochoa et al., 2016); reported potential equations for all species, but Ichthyoelephas humeralis, A. rivulatus and Pseudocurimata sp. with negative allometric growth, while Hoplias microlepis, Brycon sp. and Leporinus ecuadoriensis. Differences between growth types can be related to many factors, such as differences in sample sizes, specimen size ranges, genetic differences between groups of species, and local environmental conditions. Furthermore, parameters of the length-weight relationship may differ not only between species but also between populations of the same species, considering that the growth coefficient depends on genetic, nutritional and environmental differences.

Other studies report similar results, and report that different factors may influence this behavior, such as: sample range, seasonality, habitat, gonad maturity, stomach fullness, and development phase, among others (Sharma et al., 2015).

The biochemical indicators of the blood did not show differences when interacting the locality with sex, for which the values of the effect of the localities and the effect of sex were shown. For glucose the highest value was reflected by Fumisa, followed by Mocache. The lowest was shown by Quevedo, and differences appear between the three locations. When evaluating the sexes, the males showed the highest amount of glucose (table 3 ). can be affected by hypoxic stress, this is altered by animal density, therefore, These parameters are fundamental to know the state of the animal, to recognize the failures that appear in the system due to internal elements such as water quality, and external elements such as management (Vargas, 2019).

Other studies on hematological parameters of Brycon amazonicus (Bryconidae) and Astronotus ocellatus breeders found glucose and cholesterol levels of 60.2-64.39 mg.dL. ${ }^{1}$ and 253.4 mg.dL ${ }^{-1}$ concentrations considered normal in the range of 14.7$155.3 \mathrm{mg} . \mathrm{dL}^{-1}$ and 78 at $397 \mathrm{mg} . \mathrm{dL}^{-1}$ according to the literature. Results lower than those reported in this investigation $\left(311 \mathrm{mg} \cdot \mathrm{dL}^{-1}\right.$ for glucose) and higher than $241 \mathrm{mg} \cdot \mathrm{dL}^{-1}$ for cholesterol. Such variations of these hematological parameters can be attributed to intra- and interspecific factors such as sex, age, gonadal maturation, genetic variation, habitat, eating habit, climate, and stress caused during handling (Ahmadniaye Motlagh et al., 2020).

\section{Conclusions}

There is interaction between habitat locations and sex for different morphometric indicators evaluated. The males presented greater size, weight and thickness in the studied measurements of the body, but the females presented the highest corporal indices. The biochemical indicators were conditioned by the habitat and without interaction.

Table 3. Indicators of the blood biochemistry in males and females of Andinoacara rivulatus from three habitats.

\begin{tabular}{|c|c|c|c|c|c|c|c|c|c|}
\hline \multirow{2}{*}{$\begin{array}{l}\text { Indicators, } \\
\text { mg.dL }^{-1}\end{array}$} & \multicolumn{5}{|c|}{ Habitat } & \multicolumn{4}{|c|}{ Sex } \\
\hline & Mocache & Fumisa & Quevedo & $\mathrm{SE}^{1} \pm$ & $P$ & Females & Males & $\mathbf{S E}^{1} \pm$ & $P$ \\
\hline Glucose & $231.33^{\mathrm{b}}$ & $311.00^{\mathrm{a}}$ & $79.00^{c}$ & 5.26 & 0.001 & $222.22^{\mathrm{a}}$ & $185.33^{\mathrm{b}}$ & 6.9 & 0.002 \\
\hline Cholesterol & $169.17^{\mathrm{b}}$ & $128.67^{\mathrm{c}}$ & $241.33^{\mathrm{a}}$ & 3.77 & 0.002 & 164.89 & 161.56 & 19.92 & 0.23 \\
\hline Triglycerides & $75.00^{\mathrm{a}}$ & $66.00^{\mathrm{b}}$ & $77.00^{\mathrm{a}}$ & 0.94 & 0.01 & $77.22^{\mathrm{a}}$ & $68.11^{\mathrm{b}}$ & 0.52 & 0.05 \\
\hline
\end{tabular}

${ }^{1} \mathrm{SE} \pm$, standard error of the Sex $x$ Habitat interaction. abcdeValues with unusual letters differ at $\mathrm{p}<0.05$, Tukey.

For cholesterol, the highest value was reflected in the town of Quevedo and the lowest was Fumisa, with significant differences between them. The sexes did not show differences when analyzing this compound. For the triglycerides Mocache and Quevedo they do not differ from each other, and the lowest value appears in Fumisa. When analyzing the sexes, females present a higher amount of triglycerides than males (table 3 ).

This was verified with the different behaviors depending on the localities. Castellanos et al. (2003), reported values lower than those of this investigation for the localities of Mocache and Fumisa in terms of glucose. These authors evaluated the yamú species, the values showed a range between 131.1 and $147.6 \mathrm{mg} . \mathrm{dL}^{-1}$. In the case of cholesterol, the results were higher, the values were between 299.5 and $365.9 \mathrm{mg} . \mathrm{dL}^{-1}$.

The study of these parameters in native fish is scarce, so it is important to analyze these hematological components such as red blood cells, leukocytes and platelets, as well as biochemical such as proteins, triglycerides, minerals, enzymes. Serum biochemistry in fish can estimate the animal's response to different factors such as: stress, diseases, nutritional imbalances. The disorders that can occur from these factors depend on the species, age, physiological phase, the concentration of cortisol, glucose and cholesterol, and

\section{Acknowledgment}

Our thanks to Don Quirola, president of the Bella Vista artisanal fishing association for his support in catching the organisms. We thank Wendy Hidalgo for technical support in processing the samples. The research was supported by the Universidad Técnica Estatal de Quevedo (UTEQ). Support project for the call FOCYCYT-7th, project PFOC7-48-2020.

\section{Cited literature}

Ahmadniaye Motlagh, H., Sarkheil, M., Safari, O. \& Paolucci, M. (2020). Supplementation of dietary apple cider vinegar as an organic acidifier on the growth performance, digestive enzymes and mucosal immunity of green terror (Andinoacara rivulatus). Aquaculture Research, 51:197205. http://dx.doi.org/10.1111/are.14364.

Andrade, P. \& Braga, F. (2005). Reproductive seasonality of fishes from a lotic stretch of the Grande River, high Paraná River basin, Brazil. Brazilian Journal of Biology, 65: 387-394. https://doi.org/10.1590/S151969842005000300003 .

Barriga, R. (2012). Lista de peces de agua dulce e intermareales del Ecuador. Revista Politécnica, 30: 83-119. https://bibdigital.epn.edu.ec/ bitstream/15000/5068/4/Peces\%20agua\%20dulce-intermareales\%20 Ecuador\%202012Politecnica30\%283\%29.pdf. 


\section{6-6 | Rev. Fac. Agron. (LUZ). 2022, 39(1): e223910. January - March. ISSN 2477-9407.}

Bastardo, H., Guedez, C. y León, M. (2004). Características del semen de trucha arcoíris de diferentes edades, bajo condiciones de cultivo en Mérida, Venezuela. Zootecnia Tropical, 22 (3), 277-288. http://ve.scielo.org/ scielo.php?script $=$ sci arttext\&pid=S0798-72692004000300006.

Castellanos, A.J.A., Benavidès, M., Hernández, G. y Eslava, P.R. (2003) Valoración hematológica y química sanguínea del yamú Brycon siebenthalae, en tres etapas de cultivo. Orinoquia, 7(1), 34-41. http:// dx.doi.org/10.15381/rivep.v30i1.14935.

Enayat Gholampour, T., Fadaei Raieni, R., Pouladi, M., Larijani, M., Pagano, M. \& Faggio, C. (2020). The Dietary Effect of Vitex agnus-castus Hydroalcoholic Extract on Growth Performance, Blood Biochemical Parameters, Carcass Quality, Sex Ratio and Gonad Histology in Zebrafish (Danio rerio). Applied Science, 10(1402), 1-10. https://doi. org/10.3390/app10041402.

Fagbuaro, O., Oso, J.A., Olurotimi, M.B. \& Akinyemi, O. (2015). Morphometric and Meristic Characteristics of Clarias gariepinus from Controlled and Uncontrolled Population from Southwestern Nigeria. Journal of Agriculture and Ecology Research International, 2, 39-45. http:// dx.doi.org/10.9734/JAERI/2015/11781.

FAO. (2019). The State of the World's Biodiversity for Food and Agriculture. Food and Agriculture Organization (FAO). Rome, Italy. http://www. fao.org/3/CA3129EN/ca3129en.pdf.

González, M., Rodríguez, J., López, M. y Vergara, G. (2016). Estimación del rendimiento y valor nutricional de la vieja azul (Andinoacara rivulatus). Revista de Investigación Talentos, 3 (2), 36-42. https://talentos.ueb.edu. ec/index.php/talentos/article/view/61.

González, M.A. (2017). Características morfométricas, meristicas, de la canal y de la carne de especies de pez nativas de agua dulce de Ecuador. [Tesis Doctoral, Universidad de Córdoba]. Repositorio Universidad de Córdoba, España. https://helvia.uco.es/bitstream/ handle/10396/15214/2017000001642.pdf?sequence=1\&isAllowed=y.

Holden, M. J., y Raitt, D. F. S. (1975). Manual de ciencia pesquera. Parte II Métodos para investigar los recursos y su aplicación (Documento técnico 115). Roma, Italia: FAO. https://www.fao.org/3/f0752s/ f0752s00.htm.

Jiménez Prado, P., Aguirre, W., Laaz Moncayo, E., Navarrete Amaya, R., Nugra Salazar, F., Rebolledo Monsalve, E. y Zárate Hugo, E. (2015). Guía de peces para aguas continentales en la vertiente occidental del Ecuador. Pontificia Universidad Católica del Ecuador, Sede Esmeraldas (PUCESE), Ecuador. http://inabio.biodiversidad.gob.ec/wp-content/ uploads/2019/02/GUIA\%20PECES\%20DEL\%20OCCIDENTE.pdf.

Jiménez-Segura, L. F., Galvis-Vergara, G., Cala, P., García-Alzate, C. A., LópezCasas, S., Ríos-Pulgarín, M. I. \& Álvarez-León, R. (2016). Freshwater fish faunas, habitats and conservation challenges in the Caribbean river basins of north-western South America. Journal of Fish Biology, 89, 65-101. https://doi: 10.1111/jfb.13018.

Kerguelen-Durango, E. \& Atencio-García, V. (2015). Environmental characterization of the reproductive season of migratory fish of the Sinú River (Córdoba, Colombia). Revista MVZ Córdoba, 20, 4766-4778. http://www.scielo.org.co/pdf/mvz/v20n3/v20n3a10.pdf.
Landines, M., Prieto, C., Rodríguez, L. y Rosado R. (2017). Perfil de esteroides sexuales del capitán de la sabana (Eremophilus mutisii) durante un ciclo hidrológico completo. Revista U.D.C.A Actualidad y Divulgación Científica. 20(1), 43-50. https://doi.org/10.31910/rudca.v20.n1.2017.61

Méndez-Martínez, Y., Pacheco-Morales, G. K., Del Barco-Ibarra, K. A., TorresNavarrete, Y. G., \& Hernández-Vergara, M. P. (2021). Biochemical and immune response in red tilapia (Oreochromis mossambicus $\times$ O. niloticus) with dietary chitosan supplementation. Revista de la Facultad de Agronomía. (LUZ), 38(4), 1016-1034. https://doi. org/10.47280/RevFacAgron(LUZ).v38.n4.15

Moreno, J. M., Aguilar, F.A., Boada, N. S. y Rojas, J. A. (2019). Análisis morfométrico e índices corporales del capitán de la sabana (Eremophilus mutisii). Revista de Medicina Veterinaria y de Zootecnia, 66(2), 141143. http://dx.doi.org/10.15446/rfmvz.v66n2.82433.

Nugra, F., Anaguano Yancha, F., Arízaga, C., Zárate, E. y Brito, J. (2018). Leucismo en el pez Lebiasina bimaculata (Characiformes: Lebiasinidae) en Guayas, Ecuador. Biota Colombiana, 19(2), 133-139. http://dx.doi.org/10.21068/c2018.v19n02a12.

Ochoa Ubilla, B.Y., Mendoza Nieto, K.X., Vivas Moreira, R., Undánigo Zambrano, J. y Ferrer Sánchez, Y. (2016). Estructura de tallas de captura y relación longitud-peso de peces nativos en el humedal Abras de Mantequilla, Ecuador. Ciencia y Tecnología UTEQ, 9(2), 19-27. http://dx.doi.org/10.18779/cytuteq.v9i2.19.g8.

Revelo, W. y Laaz, E. (2012). Catálogo de peces de aguas continentales de la provincia de Los Ríos-Ecuador. Instituto Nacional de Pesca, Boletín Especial, 3(5), 1-57. https://docplayer.es/64073907-Catalogo-de-pecesde-aguas-continentales-de-la-provincia-de-los-rios-ecuador.html.

Rodríguez Pulido, J.A., Mira López, T.M. y Cruz Casallas, P.E. (2018). Determinación, diferenciación sexual y pubertad en peces. Orinoquia, 22(1), 80-91. https://doi.org/10.22579/20112629.487.

Sharma, N.K., Mir, J.I., Singh, R. \& Akhtar, M.S. (2015). Length-weight relationships for eight fish species from the Ravi River, north-western India. Journal Applied Ichthyology, 31, 1146-1147. http://dx.doi. org/10.1111/jai.12836.

Solomon, S.O., Okomoda, V.T. \& Ogbenyikwu, A.I. (2015). Intraspecific morphological variation between cultured and wild Clarias gariepinus (Burchell) (Clariidae, Siluriformes). Archives of Polish Fisheries, 23, 53-61. http://dx.doi.org/10.1515/aopf-2015-0006.

Trinder, P. (1969). Determination of Glucose in blood using glucose oxidase with an alternative oxygen acceptor. Annales of Clinical Biochemistry, 6, 24-27. http://dx.doi.org/10.1177\%2F000456326900600108.

Turán, C., Oral, M., Öztürk, B. \& Düzgüneş, E. (2006). Morphometric and meristic variation between stocks of Bluefish (Pomatomus saltatrix) in the Black, Marmara, Aegean and northeastern Mediterranean Seas. Fisheries Research, 79, 139-147. http://dx.doi.org/10.1016/j. fishres.2006.01.015.

Vargas, M. (2019). Parámetros hematológicos y bioquímicos del capitán de la sabana en diferentes sistemas de explotación. Zoociencia, 6(1), 1-6. https://revistas.udca.edu.co/index.php/zoociencia/article/view/1283. 